\title{
Quality validation of learning outcomes test instrument of core courses in Polytechnics Health Jakarta II, Indonesia
}

Iskari Ngadiarti $^{1,2}$, Arif Jauhari ${ }^{1,2}$, Syarifah El Jannah ${ }^{1,2}$, Joko Sulistyo ${ }^{1,2}$, Febi Dwirahmadi ${ }^{3}$

\author{
${ }^{1}$ Indonesia Doctoral Forum of Health Polytechnic \\ ${ }^{2}$ Politeknik Kesehatan Kemenkes Jakarta II, Indonesia \\ ${ }^{3}$ Faculty of Global Health, Griffith University, Gold Coast, Australia
}

Corresponding author:

Iskari Ngadiarti (iskaringadiarti@gmail.com)

\begin{abstract}
:
The congruence of learning outcomes and learning achievement test instrument need to be appropriate so that graduates are competent. To evaluate the process of developing learning outcome tests and content validity in the Diploma Program of Polytechnics Health Jakarta II. Survey, descriptive and cross sectional. Collecting data about the validation of learning outcome test questions is done by looking at how the lecturer develops the learning outcomes test and the quality of the test instrument. The development of learning outcomes test questions was carried out with a questionnaire on 40 lecturers randomly selected and content validity data obtained from the exam questions and semester learning plan one expertise courses from seven majors. The questionnaire for the development of learning outcomes was modified by Munadi, while content validation used Lawshe coefficient with a validator number of five people. Descriptive quantitative analysis. Development of $71 \%$ learning test is a combination of essay and multiple-choice questions, $63 \%$ of lecturers make question boxes, $33 \%$ of lecturers always validate the problem with competency or learning achievement and only $22 \%$ of lecturers adjust the questions with the indicators. The content validation ratio is 0.90 with a panel of five experts. The commitment of lecturers and institusions to maintain the quality of the learning outcomes test instrument that is integrated so that evidence based practice needs to be improved so that graduates quality is maintained.
\end{abstract}

Keywords: Content validity and core courses, development of learning outcomes test, graduate quality

How to cite this article: Ngadiarti et al. (2020): Quality validation of learning outcomes test instrument of core courses in Polytechnics Health Jakarta II, Ann Trop \& Public Health, 23 (S8):

1259-1266. DOI: $\underline{\text { http://doi.org/10.36295/ASRO.2020.23811 }}$

\begin{abstract}
Introduction
Quality assurance is one of the determinants of the existence and sustainability of a higher educational institution. Regulation of the Minister of Research, Technology and Higher Education of the Republic of Indonesia number 44, 2015 concerning the national standard of higher education has emphasized that each university is required to achieve the highest quality in order to be able to compete nationally and globally ${ }^{(1)}$. The quality assurance program is performed through monitoring, evaluation and improvement activities as a continuous and systematic quality improvement and improvement of all aspects of education both input, process and output ${ }^{(2)}$. Polytechnic of Health Jakarta II, Indonesia is one of the higher educational institutions whose mission is to improve the quality of education, research and community service delivery in accordance with science and technology and to create character and competitive health workers. Based on 2017 self-evaluation data, it shows that the productivity of graduating on time is more than $90 \%$, and the grade point average (GPA) above 2.75 has reached $100 \%$. This is not in line with the results of the try-out of the relatively low student competency test which is still below $30 \%{ }^{(3)}$. Based on this educational process evaluation, assessment process needs to be done, especially to the subjects of expertise or core courses. Core courses are subjects that characterize educational goals in the form of science and skills identifiers, work skills, behavioral attitudes in work and ways of life in the community, as a minimum requirement that must be achieved by students in completing study programs or characterizing graduate competencies ${ }^{(4)}$. Constitutional Law number 36 year 2014 stipulates that higher education in health at the end of the program must have a competency test to ensure that there is no disparity in the quality of graduates among other health educators ${ }^{(5,6)}$. Competency test is a requirement for graduates to obtain a competency certificate and this certificate is used as an application for Registration Certificate Letter, which is a prerequisite for graduates to
\end{abstract}


work in the health sector. Every health educational institution wants to pass a high competency test because it is an indicator of good management and an institution's selling point ${ }^{(7)}$. Graduation of an exam, including a competency test, is based not only on student intelligence, but is also determined by the quality of the measuring instrument or exam questions and often students practice with similar questions.

Polytechnic of Health Jakarta II has implemented a learning assessment standard by applying various methods and various assessment tools to obtain information about the extent to which student competency is being achieved. Assessment is a process for making decisions using information obtained through measurement of learning outcomes both using tests and non-tests ${ }^{(8)}$. The assessment result can be used as diagnostic information about the student's academic progress to improving the educational program. The assessment should aim at testing individual attainment of desired learning outcome based on the standard of performance of an individual's learning achievement ${ }^{(9)}$. One of the requirements in the ISO 9001:2000 quality management system related to the measurement and assessment of student learning outcomes is that the measurement tools have been validated so that they meet the rules of quality measurement tools. However, developing quality questions cannot be separated from the ability of lecturers and supporting facilities. In Permendiknas (Peraturan Kementerian Pendidikan Nasional - Ministry of National Education Regulations) number 20 year 2007 it is written that the assessment of learning outcomes can be in the form of observation tests, assignments, and other forms in accordance with the characteristics of competency and student development ${ }^{(10)}$. The states that learning outcomes tests can be made in the form of description, objective form. Assessment of learning outcomes can also be done in various ways including performance assessment, attitude assessment, written assessment, product assessment, assessment through the collection of student work and self-assessment ${ }^{(11)}$. A test will give importance if the items test has learning objectives and represent parameter to evaluate of knowledge, abilities and skills in a representative manner. The steps in the development of learning outcomes tests can be done in several stages including: The first determining the purpose of the test, the second preparation of the test lattice, third writing questions, fourth review of questions, fifth test questions including the analysis, sixth assembly of questions into test kits, seventh test presentation, eighth is scoring, ninth reporting of test results and the tenth utilization of test results ${ }^{(12,13)}$.

According to Jalinus et al. set seven steps in the development of learning outcomes tests based learning model can improve learning activity that have meaningful for students. The seven steps: The first a formulating the expected learning outcome, second understanding the concept of teaching materials, the third skill training, fourth designing the project theme, fifth making the project proposal, sixth executing the tasks of project and the seventh presentation of the project report (14). Measurement is an activity before conducting an assessment. But the important thing the precede measurement are the availability of instruments or measuring instruments or test kits. This instrument or test can describe the level of measurement results. Therefore, before making measurements it is better to first test the validity and reliability of the test tool or instrument. Validity comes from the word validity which means how carefully a measuring instrument performs its measurement function ${ }^{(15)}$. While reliability or reliability refers to the degree of a test that is able to measure various attributes consistently ${ }^{(12)}$. A low-quality problem will reduce the function of the test and can even give misleading measurement results ${ }^{(8)}$. Therefore, validity of the student achievement test results is needed. A question is said to be of quality if the items made have high validity ${ }^{(9)}$.

According to Siddick, one of the techniques for testing the validity of learning outcomes test tools is content validity. A test tool is said to have content validity when measuring certain specific objectives that are parallel to the material or content of a given lesson ${ }^{(11)}$. Content validity is validity that is an important notion for measurement of skills and knowledge that are frequently employed in evaluation studies. Instruments or measuring instruments in addition to comprehensive contents, must also contain relevant content and not go beyond the boundaries of the measurement objectives. A valid test is the test which affords satisfactory evidence of the degree to which the students are actually reaching the desired objectives of teaching, these objectives being specifically stated in terms of tangible behaviour. This validity estimation does not involve statistical computerization, but only with rational analysis it is not expected that everyone will agree and agree with the extent to which the validity of the contents of a measuring instrument has been achieved. The advantage of content validity is that it can help the contract validity and give confidence to the educating community that this instrument has involved experts to examine the feasibility of the instrument in terms of concept and operationalization ${ }^{(16)}$. The method of evaluating a test is said to be good Lawshe proposes a coefficient validity ratio (CVR) to measure the degree of agreement of experts from one item and which can express the level of content validity through a single indicator that ranges from -1 to $1^{(17)}$. Whereas other analyses is to use the coefficient of validity Aiken's v ${ }^{(18)}$. Polytechnic of Health Jakarta II in measuring the quality of its graduation is currently only based on the level of attendance of lecturers and students, graduate GPA, and the waiting period to get a job ${ }^{(3)}$. Analysis of the test results of student learning outcomes has never been done. Therefore, in this study, researchers wanted to conduct a study of how the form of student 
achievement test questions developed by the Polytechnic of Health Jakarta II lecturer and what steps were taken in compiling the learning outcomes test. Besides that, we also want to measure how the quality of the questions is seen from the aspect of content validity by using Lawshe ratio analysis ${ }^{(13)}$ and proceed with preparing a follow-up plan in order to improve the quality of the education process.

\section{Materials and Methods}

Polytechnic of Health Jakarta II in measuring the quality of its graduation is currently only based on the level of attendance of lecturers and students, graduate GPA, and the waiting period to get a job ${ }^{(3)}$. Analysis of the test results of student learning outcomes has never been done. Therefore, in this study, researchers wanted to conduct a study of how the form of student achievement test questions developed by the Jakarta Health Polytechnic lecturer and what steps were taken in compiling the learning outcomes test. Besides that, we also want to measure how the quality of the questions is seen from the aspect of content validity by using Lawshe ratio analysis ${ }^{(14)}$ and proceed with preparing a follow-up plan in order to improve the quality of the education process. Data collection related to the type of questions and the steps of composing the questions is done by questionnaire. The way to collect data is by questionnaire and reviewing the question documents that exist in each study program. The questionnaire was the result of the development of the Munadi research ${ }^{(13)}$. Data validity of the content of the test results was taken from the RPS and a collection of questions in the academic units of each study program. The data collected was analyzed descriptively quantitatively. The analysis is focused on describing in the form of a percentage of the steps taken by the lecturer in the process of planning and developing questions. Measuring content validity is done by using the Lawshe ratio by tapping five experts.

\section{Results}

\section{Forms of questions and preparation of signs:}

Based on the results of the analysis in figure 1, it appears that most (more than half), $71 \%$ of Poltekkes Jakarta II lecturers make the form of questions by combining multiple choice forms, essays and short answers, while around $29 \%$ make questions in the form of multiple choice, and about $21 \%$ make questions in essay form.

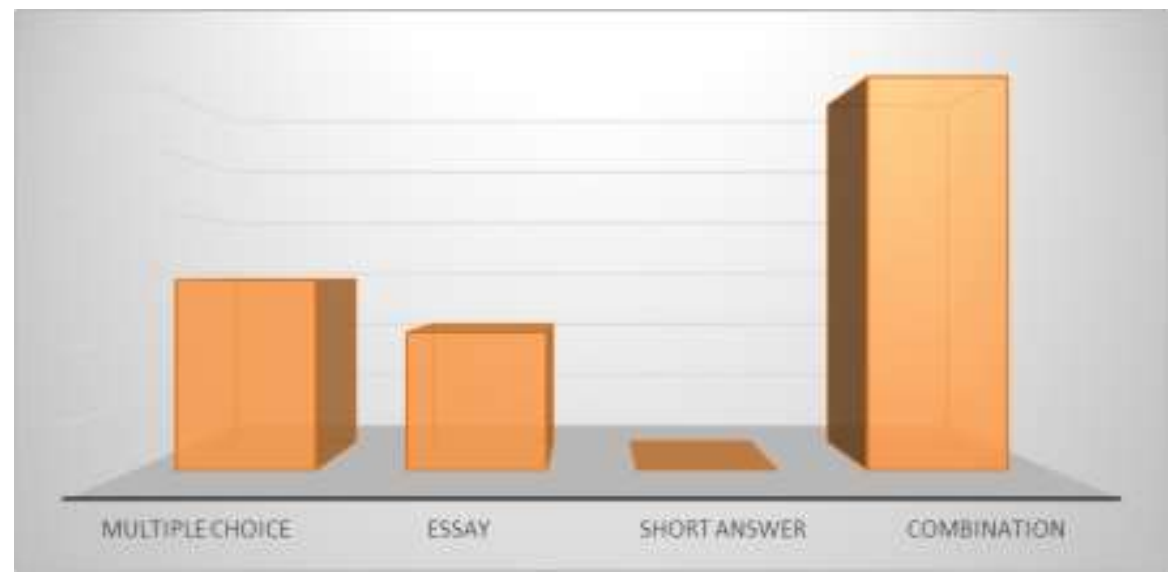

Figure 1. Percentage of number of lecturers in making questions 
Ngadiarti et al. (2020): Quality validation of learning outcomes May 2020 Vol. 23 Issue 8

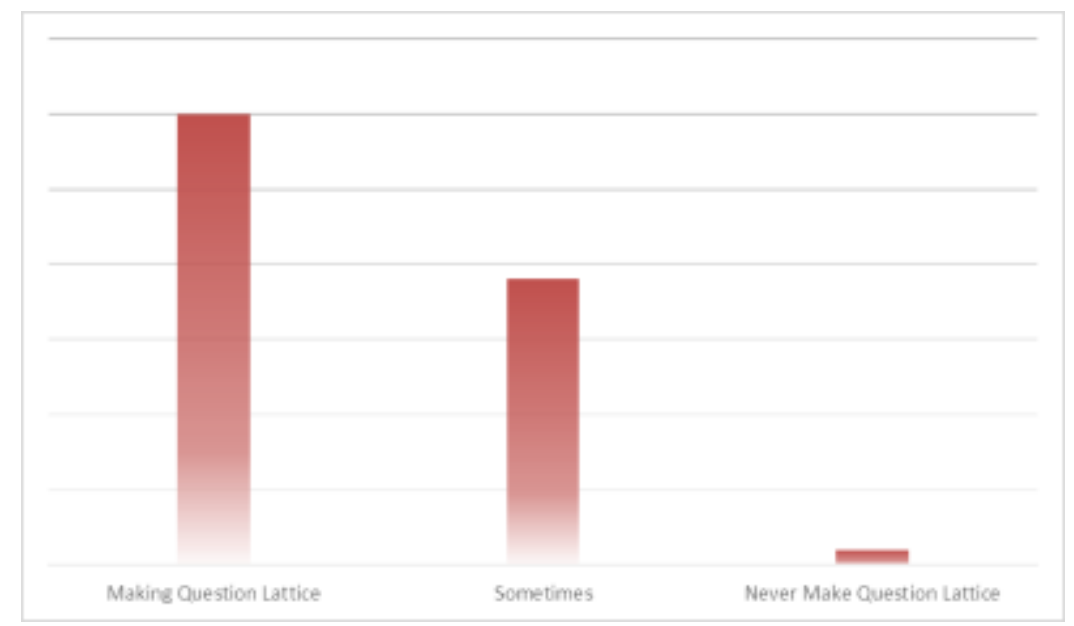

Figure 2. Percentage of the number of lecturers in making an examination preparation

While based on the results of the analysis shown in figure 2, it can be seen that the majority of Polytechnics Health Jakarta II lecturers make a grid of questions before conducting an exam. This is done to give an overview to students before taking the exam.

Item development and questions validation:

The writing of the questions and the validation of the questions are illustrated in figure 3 and figure 4 .

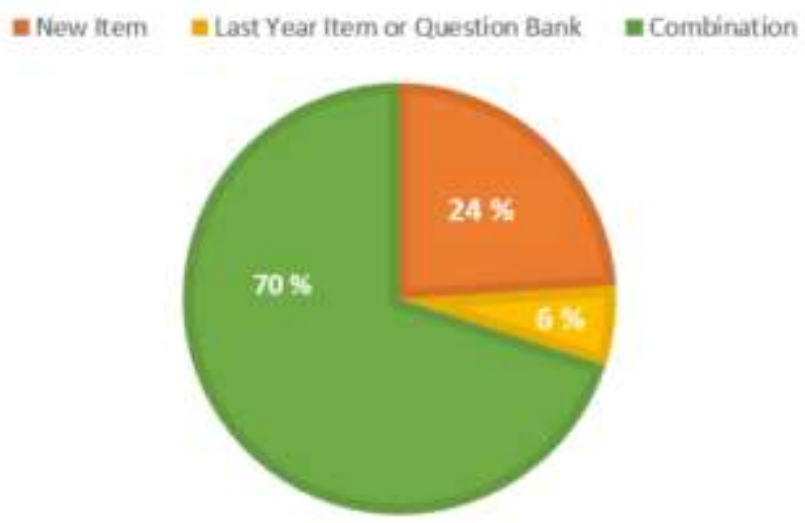

Figure 3. Percentage of number of lecturers in writing tests

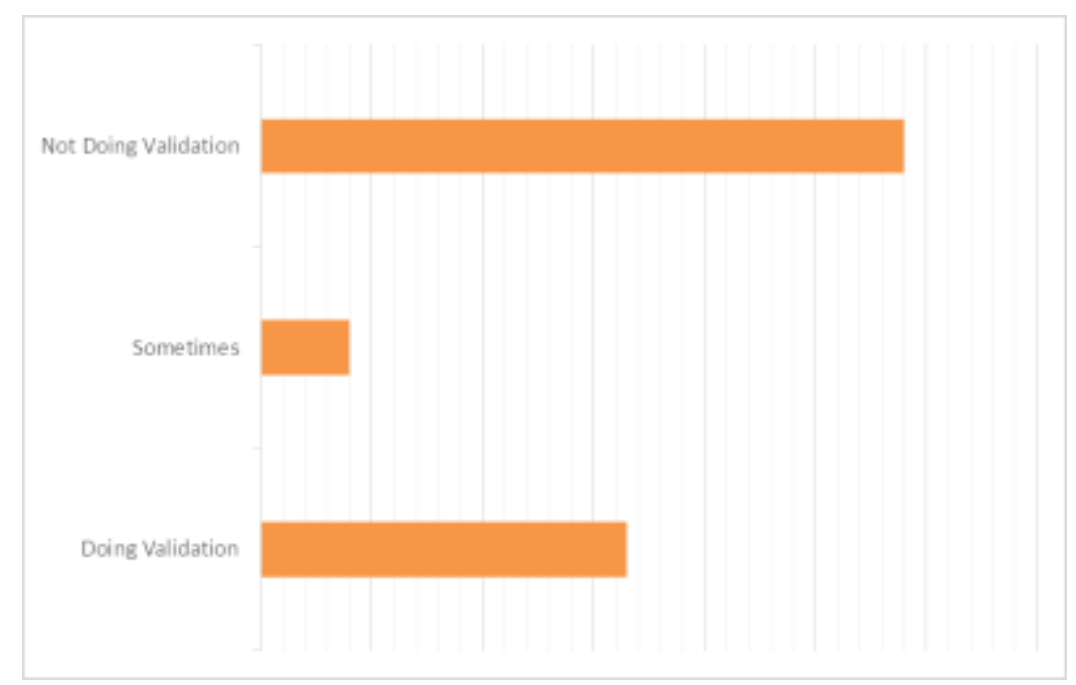


Figure 4. Percentage of number of lectures in question validation

Based on the results of the analysis in figure 3, in writing the exam questions most of the Polytechnics Health Jakarta II lecturers made questions in the form of combinations by combining last year's questions or question banks and making new questions and the rest creating new questions. While from the results of the analysis in Figure 4, the majority of which are $58 \%$ or more than half of Polytechnics Health Jakarta II lecturers sometimes validate the questions made, while only a quarter of lecturers do validation, and only a small proportion of lecturers do not validate.

\section{Study of theoretical questions and objective questions:}

The aspects taken into account in making theoretical and objective questions are illustrated in figure 5 and figure 6 . Based on the description of the data above, it can be stated that the aspects examined in the theoretical test (description) are the suitability of the questions with competence that is $35 \%$. While the smallest percentage in assessing the quality of the questions is the clarity of the scoring guideline of $2 \%$. Another thing to note is the clarity of the questions and answers $26 \%$, clarity of instructions on how to work about $12 \%$, picture or graphic or else table clarity of $5 \%$ and simplicity of language use $20 \%$.

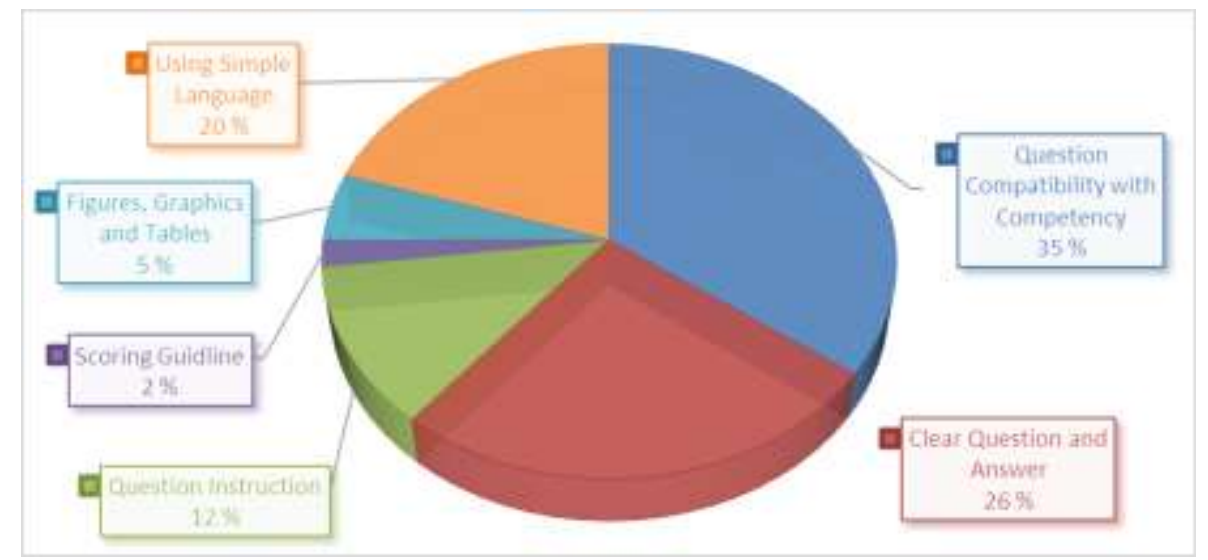

Figure 5. Percentage of number of lecturers in reviewing the quality of theoretical questions

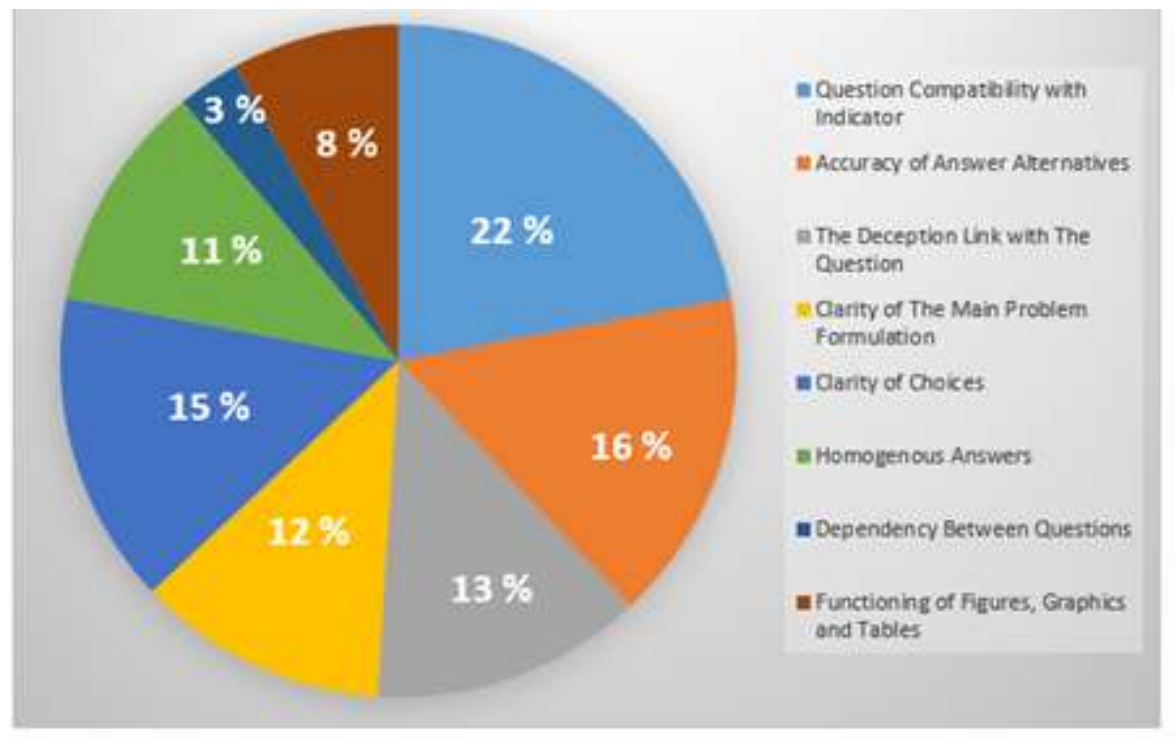

Figure 6. Percentage of number of lecturers in studying objective questions

Based on the description of the data in figure 6 , it can be seen that all aspects relating to the quality of the questions have been objectively carried out by Polytechnics Health Jakarta II lecturers. The biggest percentage 
obtained is from the aspect of the suitability of the problem with the indicator that is $22 \%$, while the smallest percentage is from the aspect of interdependence between items that is $3 \%$.

\section{Content validity:}

The results of the measurement of content validity that refer to Lawshe's CVR (content validity ratio) get a result of 0.90 . The score was obtained from a panel of experts as many as five people answered each item with a learning achievement test item with three answer choices namely, the first important and appropriate, the second appropriate but not important, and the third not needed. After that the important values are added up and entered in the Lawshe formula. The formula proposed by Lawshe is:

$\operatorname{CVR}=($ ne $-\mathrm{N} / 2) /(\mathrm{N} / 2)$

where CVR is the content validity ratio, ne is the number of panelists who answer "important", $\mathrm{N}$ is the total number of panelists. A value of 0.90 on the Lawshe limit with a panel of five people is not included in the valid category, said to be valid if the value is 0.99 .

\section{Discussion}

Core courses at Polytechnic Jakarta II are subjects that characterize graduate competencies as a health worker. Some health education experts state that education programs and curricula are key to shapig health professional knowledge, skills and attitudes, from graduates so as to improve the quality of services provided ${ }^{(19)}$. Health education needs to integrate academic and professional curriculum. Therefore, in the development of learning outcomes instruments in the academic curriculum is emphasized on knowledge that leads to skills. For this reason the form of learning outcomes tests needs to be combined between objective forms and essay that are complemented by cases in the real world ${ }^{(20)}$. If it is associated with the above results, it appears that the development of test results development by lecturers in the Jakarta Health Polytechnic environment still requires improvement and joint commitment between lecturer and educational institution. Considering there are still some lecturers who emphasize only one model, namely the objective test or essay test, whereas to improve the quality of service, the emphasis is on the acquisition and development of knowledge, attitudes and skills for successful implementation in practice. This was confirmed by Shaney et al., which states that a person is said to be competent if he is able to choose and use an integrated combination of knowledge, skills and attitudes with the intention to develop a task in a certain context ${ }^{(21)}$. Term of the development of learning outcomes test planning: Some lecturers still do not make grids, use the exam question from the previous year and do not synchronize with the goals of education and graduate's competencies. Therefore Jalinus et al. said that emphasizes that in developing a test of learning outcomes it is necessary to make a grid of questions and adjust to the goals and learning outcomes, using language and format that is easily understood (there needs to be a trial and consultation with experts); adjust to the resources possessed by the institution including the setting and emphasize the number of pass bats and conduct evaluations both to students and institutions, as material for improvement and maintain accountability ${ }^{(14)}$. Matters related to the quality of the learning outcomes instrument are carried out with content validation based on Lawshe's ratio. The results of the content validation study show that the coefficient validation ratio (CVR) of 0.90 indicates that the items used for the test of learning outcomes already show content validaty rather well because of the importance of more than $50 \%$. But based on Lawshe benchmark with five panelists, it is said to be valid or good if the value is the same as 0.99. this is also consistent with the opinion of Haynes et al. that the conditions for accepting a valid instrument if the average congruency percentage (ACP) value is greater than $90^{(22)}$. This shows that the content validaty of science and health services that are more complex and the community demands are so hight.

\section{Conclusions}

The validation of the quality of the results of the Jakarta Health Polytechnic learning outcomes test II is still not good, so the commitment of lecturers and institutions is still needed. It was suggested that maintaining the quality of the learning outcomes test instrument which integrated with evidence based practice is a standard and professional requirement beside accreditation. In addition, research that refers to improving the quality of graduates and health services.

\section{Acknowledgement}

A big thank you, from the author to the Directors Head of the Department and also the lecturer of core courses of Health Polytechnic Jakarta II who have helped in this data collection process. The acknowledgments were also conveyed to lecturers from various institutions including Malang Health Polytechnic of Indonesia, Semarang Health Polytechnic of Indonesia, Thamrin Nutrition Department of Indonesia, and professional association who are willing as a team of experts in studying the instrument of learning outcome evaluation. 


\section{References}

1. Kumar S, Anuar MSH, Abdullah SN, and Han BL. Quality health care in Brunei Darussalam: The growing impact of allied health professions. Brunei International Medical Journal. 2015; 11(4): p. 173-181.

2. Busari JO. Comparative analysis of quality assurance in health care delivery and higher medical education. Advances in Medical Education and Practice. 2012; 3: p. 121-127.

3. Wikipedia. Politeknik Kesehatan Kementerian Kesehatan Jakarta II [Jakarta Health Polytechnic Ministry of Health II]. [online]. 2015. [cited 20 December 2019]. Available from https://id.wikipedia.org/wiki/Politeknik_Kesehatan_Kementerian_Kesehatan_Jakarta_II [in Bahasa Indonesia].

4. Menteri Pendidikan Nasional [Minister of National Education]. Keputusan Menteri Pendidikan Nasional Republik Indonesia no. 232/U/2000: Tentang pedoman penyusunan kurikulum pendidikan tinggi dan penilaian hasil belajar mahasiswa [Decree of the Minister of National Education of the Republic of Indonesia no. 232 / U / 2000: About guidelines for preparing a tertiary education curriculum and evaluating student learning outcomes]. [online]. Jakarta. 2018 [cited 20 December 2019]. Available from. https://mpd.umsida.ac.id/wp-content/uploads/2018/01/232u2000.pdf [in Bahasa Indonesia].

5. Kementerian Kesehatan Republik Indonesia [Ministry of Health of the Republic of Indonesia]. Undangundang Republik Indonesia nomor 36 tahun 2014: Tentang tenaga kesehatan [Law of the Republic of Indonesia number 36 of 2014: Regarding health workers]. [online]. Jakarta. 2014 [cited 20 December 2019]. Available from http://gajiroum.kemkes.go.id/data/UU_NO_36_2014.pdf. 28 p.

[in Bahasa Indonesia].

6. Atmadjaja A. Panduan pelaksanaan uji kompetensi sarjana kesehatan masyarakat Indonesia (UKSKMI) Tahun 2017 [Guidelines for implementing the competency test for Indonesian public health (UKSKMI) 2017]. Jakarta: RISTEKDIKTI (riset, teknologi dan pendidikan tinggi) [RISTEKDIKTI (research, technology and higher education)]. 2017. 25 p. [in Bahasa Indonesia].

7. Kementerian Riset, Teknologi, dan Pendidikan Tinggi. Peraturan Menteri Riset, Teknologi, dan Pendidikan Tinggi Republik Indonesia no. 12 tahun 2016: Tentang tata cara pelaksanaan uji kompetensi mahasiswa bidang kesehatan [Republic of Indonesia Minister of Research, Technology and Higher Education Regulation no. 12 of 2016: About the procedures for carrying out student competency tests in the health field]. [online]. Jakarta: Berita Negara Republik Indonesia. 2016 [cited 20 December 2019]. Available from http://www.aptfi.or.id/dokumen/2016-05-29\%20Permenristekdikti\%20No\%2012-

2016\%20tentang\%20Uji\%20Kompetensi\%20Nakes.pdf . 7 p. [in Bahasa Indonesia].

8. Ramona L and Bran C. The assessment of learning outcomes. Procedia-Social and Behavioral Sciences. 2014; 163: p. 125-31.

9. Mugimu CB and Mugisha WR. Assesement of learning in health sciences education: MLT case study. Journal of Curriculum and teaching. 2017; 6(1): p. 21-34.

10. Kementerian Pendidikan Nasional (Ministry of National Education). Peraturan pendidikan nasional Republik Indonesia no. 20 tahun 2007 tentang standar penelitian [Republic of Indonesia's national education regulation no. 20 of 2007 concerning research standards]. [online]. 2007 [cited 20 December 2019] Available from https://luk.staff.ugm.ac.id/atur/bsnp/Permendiknas20-2007StandarPenilaian.pdf [in Bahasa Indonesia].

11. Siddiek AG. The impact of test content validity on language teaching and learning. Asian Social Science. 2010; 6 (12): p. 133-143.

12. Brenan RL. Educational Measurement ACE/ Praeger series on higher education (4 $4^{\text {th }}$ ed.). American Council on Education: Praeger Publishers. 2006. 808 p.

13. Munadi S. Analisis validasi kualitas soal tes hasil belajar pada pelaksanaan program pembelajaran [Analysis of the validation of the quality of the test results of learning outcomes in the implementation of learning programs]. Cakrawala Pendidikan. 2011; 30(1): p. 145-159. [in Bahasa Indonesia].

14. Jalinus N, Nabawi RA, and Mardin A. The seven steps of project based learning model to enhance productive competences of vocational students.advances in social science. Education and Humanities Research. 2017; 102: p. 251-256.

15. Ali HIH and Ajmi AASA. Exploring non-instructional factors in student evaluations. Higher Education Studies. 2013; 3(5): p. 81-93.

16. Sue B and Boyd P. Developing effective assesment in higher education: A practical guide ( $1^{\text {st }}$ ed.). New York: Open University Press. 2007. 257 p.

17. Lawshe CH. A quantitative approach to content validity. Personnel Psychology. 1975; 28(4): p. 563-575.

18. Aiken LR. Content validity and reliability of single items or questionnaires. Educational and Psychological Measurement. 1980; 40(4): p. 955-959.

19. Lehane E, Warren PL, O’Riordan C, Savage E, Drennan J, O’Tuathaigh C, et al. Evidence-based practice 
Ngadiarti et al. (2020): Quality validation of learning outcomes May 2020 Vol. 23 Issue 8

aducation for healthcare professions: An expert view. BMJ Evidance-Based Medicine. 2019; 24: p.103-108.

20.Lewis LK, Williams MT, and Olds TS. Development and psychometric testing of an instrument to evaluate cognitive skills of evidence based practice in student health professionals. BMC Medical Education. 2011; 11(77): p. 1-11.

21. Shaney T, Baum KD, Bell D, Feldstein D, Houston TK, Kaatz S, et al. Instruments for evaluating education in evidence-based practice: A systematic review. Journal of the American Medical Association. 2006; 296(9): p. 1116-1127.

22. Haynes SN, Richard DCS, and Kubany ES. Content validity in psychological assessment: A functional approach to concepts and methods. Psychological Assessment 1995; 7(3): p. 238-247. 